\title{
Presidential Election Results and Stock Market Performance: Evidence From Nigeria
}

\author{
A.E. Osuala ${ }^{1}$, U.A. Onoh ${ }^{1}$, G.U. Nwansi ${ }^{2}$ \\ ${ }^{1}$ Department of Banking \& Finance, College of Management Sciences, Michael Okpara University of Agriculture, \\ Umudike, Nigeria \\ 2 Department of Banking \& Finance, Federal Polytechnic, Nekede, Owerri, Nigeria \\ Correspondence: A.E. Osuala, Associate Professor of Finance, Department of Banking \& Finance, College of \\ Management Sciences, Michael Okpara University of Agriculture, Umudike, Nigeria. E-mail: \\ osuala.alex@mouau.edu.ng
}

Received: October 13, 2017

Accepted: November 13, $2017 \quad$ Available online: February 9, 2018

doi:10.11114/aef.v5i2.3016

URL: https://doi.org/10.11114/aef.v5i2.3016

\begin{abstract}
The study investigates the effect of Presidential election results on the performance of an emerging stock market using the case of the 2011 and 2015 Presidential elections in Nigeria. Adopting Event Study methodology to analyse the secondary data obtained from the Nigerian Stock Exchange (NSE) and some national dailies, the results of the study suggest that the 2011 presidential election result had negative significant impact on the performance of the stock market. On the other hand, the 2015 Presidential election result had positive but insignificant impact on the stock market as evidenced by the average and cumulative abnormal returns on the event date and one day post-event date- an indication that the result of the 2015 Presidential election was a welcomed development as leadership changed from PDP to All Progressives Congress (APC).
\end{abstract}

Keywords: election result, stock market, event study, abnormal return

\section{Introduction}

The relationship between political events and investors' behaviour in the financial market has attracted a great deal of attention in financial economics literature. Some studies have documented that prices in the financial market fluctuate consequent upon announcement of major political events such as legalization of trade unions, national labour union strike, annual budget, national elections results, etc.( Osuala \& Agbeze, 2016; Khan, Baig, Usman, Shaique \& Shaikh, 2017). Expectedly, the manner and rate at which the market reacts to political events will vary depending on the type of event being investigated and also on the "political environment" in question. It is expected that conclusions reached based on developed markets will significantly differ in comparison to emerging markets. This idea is however not in tandem with the tenets of the popular Efficient Market Hypothesis.

The basic tenet of the Efficient Market Hypothesis (EMH) of traditional finance as propounded by Fama (1991) is predicted on the supposition that the capital market is perfect and as such able to effectively build in market information into stock prices. This assumption of perfect capital market is hinged on the belief that the investors and other capital market participants are rational in their decision making process. Still, emerging facts from the field of behavioural finance have come to cast aspersions on this principle or belief held by EMH theorists.

Behavioural finance maintains, contrary to the tenet of the traditional finance, that the stock market is not altogether efficient. Furthermore, several recent research works have documented evidences of irrationality and deviations from sound investment judgements on the part of capital market participants, and have laboriously tried to prove that the stock market is not entirely efficient as claimed by EMH. Behavioural finance suggests that psychological factors influence investors' investment decisions.

Chaudhary (2013) states, "people are not always rational and markets are not always efficient, and recent research shows that the average investor makes decision based on emotion, not logic". According to Zach (2003:p2), "Fama (1990) and Schwert (1990) show that only 50\% of the market's stock price variation can be explained, ex-post, by real economic activity... We can't explain more of the variation in stock prices even with the benefits of hindsight". 
As a result of this development, more recent studies turned into examining other factors that potentially influence stock price movements that were omitted from previous research works. Some of these recent studies, such as Osuala \& Agbeze (2016) and Khan, et al., (2017) turned the search light on the political arena in search of the "missing variation", and claimed that there is a high level of correlation between political events and economic events. Among the numerous political events that are thought to have significant implication for stock price variation is Presidential election results.

Elections are an important political event that determines the direction of future economic management. Changes in policies, which are determined by election outcomes, can influence not only consumers' welfare but also firms' profits. Because of this, it is natural for investors in the market to predict election outcomes well before election days, and the election itself is regarded as an additional factor that would impact volatility around elections (Julio and Yook, 2012).

\subsection{Purpose of the Study}

The general objective of the study is to establish the link between presidential election results announcement and stock market returns in Nigeria with emphasis on 2011 and 2015 presidential elections. The specific objectives are:

1. To examine the effect of the 2011 Presidential election results on the performance of the Nigerian stock market proxied by the transformed all share index

2. To investigate the effect of the 2015 Presidential election results on the performance of the Nigerian stock market represented by the transformed all share index (i.e. stock returns)

\subsection{Statement of Hypotheses}

$\mathrm{H}_{01}$ : 2011 Presidential election results did not have significant effect on the performance of the stock market.

$\mathrm{H}_{02}: 2015$ Presidential election results did not have significant effect on the performance of the stock market.

\subsection{Contribution of the Study}

Although there is a plethora of studies on the connection between stock market performance and the announcement of elections results based on developed markets, there is rather a paucity of such works relating to emerging markets. This study is unique in the sense that there has not been a research work exploring the connection between the 2011 and 2015 presidential elections result announcement and stock market performance in Nigeria to the best of the knowledge of the authors.

\section{Literature Review}

The political economy theoretical framework provides a basis for understanding the relationship between politics and the stock market. Gilpin (2001) describes this relationship as "interactive". As is seen from the prism of historical events, businesses attempt to promote a political agenda that supports their goal (Caro, 2002). The reason that some business sectors are willing to spare massive amounts of money to promote a specific candidate or political agenda is because the winning candidate's agenda has a direct impact on the business environment.

The Nigeria's presidential elections, 2011 and 2015, were the most intense and uncertain political events in the Nigerian political history. This was as a result of the fact that the president that was of Northern extraction that was in power was succeeded before the expiration of his tenure (because he died while yet serving) by a president of southern origin, who had ruled for six years but was still in the race for another four-year tenure. Besides, there had been several other turbulent events ranging from terrorism to economic instability such that people were yearning for a new government which would bring about a change for the better.

In any democratic economy, the process of achieving and predicting the level of economic growth and performance is often pegged against stability of the country's political environment. This, according to Alesina, Spolaore and Wacziarg (1997), implies that voters tend to cast their votes based on the economic parameters such as inflation rates, interest rates, performance of the money market as well as perception on foreign investment. Voting behaviour is retrospective in that it depends on economic performance under the incumbent in the past (Kim and Mei, 2001).

Bechtel and Fuss (2010) analysed the effect of political factors, chiefly, German parliamentary election on stock performance across four sectors of the economy between 1991 to 2005, and concluded that there was higher mean return and volatility in the defence and the pharmaceutical sectors with higher tendency towards a more conservative government while there was higher mean return and higher volatility in the alternative energy sector and the consumer sector respectively, with higher probability of a left-leaning government.

Pantzalis, Stangeland and Turtle (2000) also found that there was a positive stock market reaction in the two weeks period prior to election among 33 investigated countries. The positive abnormal returns had positive relationship with the uncertainty of election results. Hsu and Yu (2005) examined the stock market returns of nine elections between 1992 and 2004 in Taiwan. Their results showed that political elections created short run positive abnormal return before elections which indicated that the election bull-run does happen in Taiwan's elections. In addition, they also found that the 
abnormal returns are even significantly higher when an incumbent government loses. This finding is consistent with Pantzaliset al., (2000) who found the existence of a strong positive abnormal returns leading to the elections being lost by the incumbent government.

Yi-Hsien , Mei-Yu, and Che-Yang, (2008) analyzed the U.S Presidential election and concluded that the effect of presidential elections on stock markets depend on the individual presidents themselves, the general policies the winning parties and nature of the market.

Onder and Mugan (2006) studied the effect of political events from 1995 to 1997 on stock returns volatility for two emerging markets, Turkey and Argentina. They concluded that political events though have impact on the stock market, such impact was not significant. Chen, Bin and Chen (2005) investigated the impact of nine (9) political events happening from 1996 to 2002 on Taiwan's stock market. They concluded that political events have significant impact on stock prices; and insisted that good news cause positive abnormal returns while negative news cause negative abnormal returns.

Summarily, it can be said that the extant literature on the impact of political events on stock returns have mixed conclusions, which therefore warrants further search or enquiry into the impact of presidential elections results on emerging stock markets.

\section{Methodology}

The study examined the effect of general elections results on the performance of the Nigerian stock market using some selected listed firms. The 2011 and 2015 Presidential elections results were used in the study and secondary data comprising of current market price and all share index sourced from Nigerian stock market daily listing were used for analysis. The judgemental sampling approach was used and each of the companies selected was expected to meet the following criteria:

i. It must have been listed in the Nigerian stock market some six months before the period of this study.

ii. It must also have the necessary data required for the study periods.

iii. It must be a company that does not have a constant current market price.

\subsection{Model Specification}

The standard event study method was used for analyzing relevant data set obtained for the study on the effect of Presidential elections results on the performance of the Nigerian stock market. An event study measures the impact of new information on the return of financial assets.

According to Osuala (2010) the basic steps in an event study are as follow:

1. Identification of the event date. This is the date on which the event occurred, that is, when the market first learnt of the event.

2. Definition of the event window. This refers to the number of trading days preceding and following the event date that are considered necessary to capture both the leakage, if any, and the time needed for the data to effectively reach the marketplace.

3. Definition of the estimation period. The estimation period is the period of time over which no event has occurred. It is used to establish how the returns should behave normally (i.e., in the absence of the event).

4. Selection of the sample of firms. This entails definition of a criterion to screen the firms.

5. Calculation of "normal" returns (the returns that would have occurred in the absence of the event). There are several approaches for characterizing the normal returns, namely, the mean return, the market return, portfolio return and risk-adjusted return. Each of the methods has its own pros and cons.

6. Calculation of abnormal returns (that is the excess return arising from the occurrence of the event of interest. To calculate the abnormal returns (ARs) you take the actual return for the sample firms for each day in the event window and you subtract the estimated normal return for each day in the event window. The cumulation of the ARs yields the cumulative abnormal returns (CARs).

7. Evaluation of the statistical significance of the (Average) Abnormal Returns and Cumulative Abnormal Returns. By determining the statistical significance of the (A)AR, you are then determining the significance of the event, which is the punch line of an event study.

The market return approach was used for characterizing the normal returns, and it is given as:

$$
R_{i t}=\alpha_{i}+\beta_{i} R_{m t}+e_{i t}
$$

where:

$\mathrm{R}_{\mathrm{it}}: \quad$ is realized rate of return of the $\mathrm{i}$-th security during period $t$, 
$\mathrm{R}_{\mathrm{mt}}$ : is rate of return on the equally-weighted market index $(m)$ at period $t$,

$\mathrm{e}_{\mathrm{it}}$ : $\quad$ is a random variable that is expected to have a mean value of zero.

$\alpha_{\mathrm{i}}, \beta_{\mathrm{i}}$ : $\quad$ are the intercept and slope parameters for the firm $i$, respectively.

The abnormal return (AR) for the $i$-th common stock on day $t$, is given by:

$$
A R_{i t}=R_{i t}-\left(\hat{\alpha}_{i}+\hat{\beta}_{i} R_{m t}\right)
$$

where $\left(\hat{\alpha}_{i}+\hat{\beta}_{i} R_{m t}\right)$ is the expected rate of return $[\mathrm{E}(\mathrm{R})]$; the coefficients $\hat{\alpha}_{i}$ and $\hat{\beta}_{i}$ are Ordinary Least Squares estimates of $\alpha_{\mathrm{i}}$ and $\beta_{\mathrm{i}}$, estimated from a regression of daily security returns on daily market returns from $\mathrm{t}=-24$ to $\mathrm{t}=-1$ $(t=-24$ to $t=-1$ is the estimation window). It should be noted however, that in an efficient market (where investors have rational or unbiased expectations), $\mathrm{E}\left(\mathrm{AR}_{\mathrm{it}}\right)=0$, where $\mathrm{E}\left(\mathrm{AR}_{\mathrm{it}}\right)$ is expected abnormal return.

The individual security's abnormal returns, $\mathrm{AR}_{\mathrm{it}}$, is aggregated and averaged across all the observations as shown below:

$$
A \bar{R}_{i t}=\sum_{i=1}^{N} \frac{A R_{i t}}{N}
$$

Where: $\mathrm{N}$ is the number of events in the sample. The reason for averaging across firms is that stock returns are noisy, but the noise tends to cancel out when averaged across a large number of firms. Finally, the average abnormal returns are then tested for their statistical significance.

Before the statistical significance of the abnormal returns can be determined, the standard deviation of the abnormal returns in the estimation period need first be computed. To do this, the following steps need to be followed:

a) For each time period $t$ in the estimation period, we calculate the average abnormal return over all securities. For example, as the estimation period in this study is 24 days and there are 20 companies in the sample, after averaging over all companies in the sample there will be 24 average abnormal returns (one for each day). Algebraically:

$$
\overline{A R}_{t}=\frac{\sum_{i=1}^{N} A R_{i t}}{N}
$$

Where: $\overline{A R}_{t}$ is the average abnormal return across all companies at time $t$ in the estimation period.

b) The average abnormal return over all companies for the whole estimation period must be calculated. To do this, we calculate the average of the average abnormal returns in the estimation period, $\overline{A R}$. Algebraically:

$$
\overline{\overline{A R}}=\sum_{i=1}^{T} \frac{\overline{A R_{t}}}{T}
$$

Where: $\overline{\overline{A R}}$ is the average abnormal return over all companies in the control period and $\overline{A R}_{t}$ is the average abnormal return over all securities in period $t$.

$\overline{A R}_{t}$ and $\overline{\overline{A R}}$ are used in the calculation of the standard deviation of the abnormal returns. Abnormal returns from the event period are not used so that the standard deviation estimate is protected from being biased by the uncharacteristic movements in share price returns during this period.

Given our estimates of $\overline{A R}_{t}$ and $\overline{\overline{A R}}$ we then calculate an estimate of the expected abnormal return standard deviation.

c) The standard deviation of the abnormal returns in the estimation period is:

$$
\sigma\left(\overline{A R}_{t}\right)=\sqrt{\frac{\sum\left(\overline{A R}_{t}-\overline{\overline{A R}}\right)^{2}}{T-1}}
$$

d) We then calculate the average abnormal return over all securities in each period in the event period. The abnormal returns $\left(\mathrm{AR}_{i t}\right)$ of individual securities is summed up and averaged across all the observations at a distinct time using the formula:

$$
\overline{A R}_{t}^{K P}=\frac{\sum_{i=1}^{N} A R_{i}^{B P}}{N}
$$

where $\mathrm{N}$ is defined as the number of firms in the sample and $t$ refers to period $\mathrm{t}$ in event time. 
By aggregating the periodic average abnormal returns over a particular time interval, L cumulatively, we obtain the cumulative average returns (CAR).

$$
C A R_{t}=\sum_{i=1}^{L} \overline{A R}_{L}
$$

and "L" stands for the time-line of the event window.

e) The concluding step is to test the statistical significance of each $\overline{A R}_{t}$ and $C A R_{t}$ in the event period. This is simply done by dividing each average abnormal return in the event period by the standard deviation estimate calculated in c) above. If we assume that the average abnormal returns over all companies are independent, identically distributed and come from a normal distribution, the test statistic is distributed as a Student's $t$ with degrees of freedom equal to (T-1). Since we have averaged the abnormal returns, data problems such as cross sectional correlation have been taken into account:

$$
t=\frac{\overline{A R}_{t}{ }^{E P}}{S(\overline{A R})}
$$

Where $\overline{A R}_{t}^{E P}$ is average abnormal return at time, $t$ in the estimation window and $S(\overline{A R})$ equals estimate of the standard deviation of the average abnormal return estimated over the estimation window.

$$
S(\overline{A R})=\sqrt{\frac{\sum_{t=1}^{T}\left(\overline{A R}_{t}{ }^{P E}-\overline{\overline{A R}}\right)^{2}}{T-d}}
$$

$\mathrm{T}$ represents length of the pre-event window,

$\mathrm{d}$ stands for the number of parameters, and

"T- $d$ " is the degree of freedom (DF)

$\overline{A R}_{t}{ }^{P E}=$ average abnormal return over all securities in period $t$ during the pre-event period.

$\overline{\overline{A R}}=$ average abnormal return over all firms in the pre-event period.

Statistically significant t-statistics implies that the event has a bearing on returns whether it indicates positive or negative effect on the returns.

For cumulative average abnormal returns, the t-test formula is:

$$
\operatorname{CAAR}\left(\mathrm{t}_{1}, \mathrm{t}_{2}\right)=\frac{\text { CAAR }}{S(\overline{A R})^{\text {? } \sqrt{N t}}}
$$

Where Nt equals the absolute value of event day, t plus 1 (Kusnadi and Sohrabian, 1999).

\section{Findings and Discussions}

\section{Presidential election results and the stock market return}

In this section we analyzed the response of the stock market to the 2011 presidential elections in Nigeria. The result of the analysis is seen in table 4.1 .

Table 4.1. Result of average abnormal returns and CAR for $\mathrm{H}_{02}$

\begin{tabular}{lllll}
\hline Event window & AAR & t-value & CAR & t-value \\
\hline-2 & -5.00279 & -5.92518 & -5.00279 & -4.1896 \\
-1 & -4.96912 & -5.88531 & -9.97191 & -6.8189 \\
0 & -4.88691 & -5.78795 & -14.8588 & -6.2727 \\
1 & -4.80852 & -5.6951 & -19.6673 & -10.4176 \\
2 & -4.7503 & -5.62615 & -24.4176 & -11.8062 \\
3 & -4.80321 & -5.6881 & -29.2209 & -11.0443 \\
\hline
\end{tabular}

Source: Compiled by the authors

The result above shows that the Nigerian stock market's response to the 2011 general election result is negatively significant at a $5 \%$ level of significance. This result indicates that 2 days prior to and till $4^{\text {th }}$ day after the occurrence of the event, the stock market returns showed a negative response to the events. The $t$-values of the abnormal returns (ARR and CAR) show a highly negative significant results which probably could be as a result of the fact that the expectation of a change in administration from the incumbent ruling party to another was dashed. 


\section{Presidential election results and the stock market return}

The hypothesis states that 2015 Nigerian general election did not have any significant effect on stock market performance. The data was analyzed using the event study methods and the result is as shown in Table 4.2.

Table 4.2. Result of average abnormal returns and CAR for $\mathrm{H}_{02}$

\begin{tabular}{llllr}
\hline Event window & AAR & t-value & CAR & t-value \\
\hline-2 & -0.79954 & -1.025 & -0.799 & -0.7239 \\
-1 & -0.44794 & -0.574 & -1.247 & -0.9225 \\
0 & 1.177137 & 1.508 & 0.070 & 0.0448 \\
1 & 0.292342 & 0.375 & 0.222 & 0.1272 \\
2 & -0.36726 & -0.471 & 0.145 & 0.0759 \\
3 & -0.82911 & -1.062 & -0.974 & -0.4717 \\
\hline
\end{tabular}

Source: Compiled by the authors

The result above indicates that, generally, the 2015 Nigerian Presidential election had an insignificant effect on the performance of the stock market. The result shows that there was an insignificant negative abnormal return 2 days prior to the event day and an insignificant positive abnormal return on the event day and, a day and two after. However, the market experienced a negative insignificant abnormal return on the third day after the event. It is evident that the market responded insignificantly to the 2015 presidential election results; however, the positive abnormal returns on the event day and two subsequent days after, is an indication that the results of the 2015 election was a welcomed change as leadership changed from People's Democratic Party (PDP) to All Progressives Congress (APC). But a reverse result was witnessed in the market on the third post-event day which could probably be as result of doubts over the ability of the new helm's man and his administration to drive the needed change in the country.

\section{Conclusion}

The main goal of this research study is to investigate the effects of presidential elections result on stock market performance using the case of 2011 and 2015 Presidential elections in Nigeria. Empirical results showed that the market reacted sensitively to Presidential election results. It can be seen that elections do affect stock market in a certain direction, depending on both the winner as well as the anticipated economic and financial policies of the new administration.

From the findings, it is concluded that the stock market's reactions to 2011 Presidential election is negative which could be attributed to an unwelcomed election results and the uncertainty surrounding it. Hence, it can be averred that information emerging from Presidential election result is useful for valuing securities in the market.

Overall, our results support the hypothesis that following an election, the market corrects, and thus reflects changes which could be related to the fears and anxiety associated with the uncertainty of future policies.

We suggest that further studies could be done to analyze the performance of stock returns consequent upon presidential election exercise in a longer event window so as to identify how favourable a certain government economic and financial policies were to investors (voters).

\section{References}

Aktas, H., \& Oncu. S. (2006). The stock market reaction to extreme events: evidence from Turkey. International research journal of finance and economics.

Alesina, A., Spolaore, E., \& Wacziarg, R. (1997). Economic Integration and Political Disintegration. The American Economic Review, 90(5). https://doi.org/10.3386/w6163

Alile, H., \& Anao. (1986). The Nigerian stock market in operation. Jeromelaiho and associates ltd, Lagos.

Allan, M. (2012). Effects of political process on the economic performance of a country: a case of Kenya general elections. Journal of economics and sustainable development, 3.

Angela, K., \& Wilson, N. (2007). Stock market performance before and after general elections- a case study of Nairobi stock exchange.

Ashton, J. K., Gerrard, B., \& Hudson, R. (2010). Do national soccer results really impact on the stockmarket? Applied economics.

Balinksi, M., \& Laraki, R. (2011). Election by majority judgement: experimental evidence in Dolez, In Situ and laboratory experiments on electoral law reform: French presidential elections springer.

Beaulieu, M., Jean, C. C., \& Naceur, E. (2006). Political uncertainty and stock market returns: evidence from the 1995 Quebec referendum. Canadian journal of economics, 39(2), 621-641. 
https://doi.org/10.1111/j.0008-4085.2006.00363.x

Chiu, C., Chen, D., \& Tang, W. (2005). Political elections and foreign investor trading in South Korea's financial markets. Applied economics letter, 12(11), 673-677. https://doi.org/10.1080/13504850500190097

David, L., \& Bumba, M. (2003). Presidential elections and the stock market: comparing Markov -switching and (FIE) GARCH models of stock volatility.

David, L., \& Bumba, M. (2005). Government partisanship, elections and the stock market: examining American and British stock returns (1930-2000). American journal of political science, 49, 780-802. https://doi.org/10.1111/j.1540-5907.2005.00155.x

Doplce, J., \& Pierdzooch, C. (2006). Politics and the stock market: evidence from Germany. European journal of political economy, 22(4), 925-943. https://doi.org/10.1016/j.ejpoleco.2005.11.004

Easaw, J., \& Gerratt, D. (2000). Elections and U.K government expenditure cycles in the 1980s: an empirical analysis. Applied economics, 32(3), 381-391. https://doi.org/10.1080/000368400322804

Fama, E. (1970). Efficient capital markets: a review of theory and empirical work. Journal of finance, 383-417. https://doi.org/10.2307/2325486

Fama, E. (1991). Efficient capital markets 11. Journal of finance, 1575-617. https://doi.org/10.1111/j.1540-6261.1991.tb04636.x

Farrell, J., \& David, M. (2011). Electoral system: a comparative introduction. New York, St. Martins press: 0-333-80162-8. https://doi.org/10.1007/978-1-137-28550-8

Gerlach, J. R. (2011). International sports and investor sentiment: do national team matches really affect stock market returns?. Applied financial economics, 21(12), 863-880. https://doi.org/10.1080/09603107.2010.543069

Gul, S., Khan, M., Saif, N., \& Rehman, S. (2013). Stock market reaction to political events: evidence from Pakistan. Journal of economics and sustainable development, 4(1), 165-174.

He, Y., Hai, L., Chunchi, W., \& Uric, D. (2009). The 2000 presidential election and the information cost of sensitive versus non-sensitive S\&P500 stocks. Journal of financial markets, 12(1), 54-86. https://doi.org/10.1016/j.finmar.2008.04.004

Hsu, C., \& Yu, W. (2005). A study on the relationship between election and Taiwan stock market. Journal of far east university, 22(2), 231-249.

Irungu, A. K. (2012). Informational content of general election results announcement at the Nairobi securities exchange. Unpublished MBA project, University of Nairobi.

Jensen, N. (2003). Nation-States and the multinational corporation: a political economy of foreign direct investment. Princeton University press.

Jensen, N. (2006). Democratic governance and multinational corporations: political regimes and inflows of foreign direct investment. International organizations, 57, 587-616.

Julio, B., \& Yook. Y. (2012). Political uncertainty and corporate investment cycles. The Journal of Finance, 67, 45-84. https://doi.org/10.1111/j.1540-6261.2011.01707.x

Kabiru, J., Ochieng, D., \& Kenyua, H. (2015). The effect of general elections on stock returns at the Nairobi stock exchange. European scientific journal, 11(28).

Khalid, A., \& Rajaguru, G. (2010). The impact of political events on financial markets volatility: evidence using Markov-switching process. Working paper series, 43, the development and globalization centre, bond University Australia.

Khan, S., Baig, N., Usman, M., Shaique, M., \& Shaikh, R. (2017). Stock Market Dynamics in Pakistan: What Do Political Events and Budget Announcements Disclose? Research Journal of Finance and Accounting, 8(10), 2017.

Kim, H., \& Mei, J. (2001). What makes a market jump? An analysis of political risk on Hong Kong stock returns. Journal of international money and finance, 20(7), 1003-16. https://doi.org/10.1016/S0261-5606(01)00035-3

Kithinji, A., \& Ngugi, W. (2009). Stock market performance before and after general elections: a case of the Nairobi stock exchange.

Kumar, D., Sophia, S., \& Jacunda, E. (2015). Empirical study on effects of Lok Sabha election on stock market performance (Bse Sensex). Journal of management science, 4(2).

Lin, C. T., \& Wang, Y. H. (2007). The impact of party alternative on the stock market: the case of Japan. Applied 
economics, 39(1), 79-85. https://doi.org/10.1080/00036840500427882

Nguthi, P. N. (2013). The effect of political news on stock market returns in Kenya: the case of March 2013 general elections. University of Nairobi.

Nwolise, O. B. (2007). Electoral violence and Nigeria's 2007 elections. Journal of African elections special issue: Nigeria's 2007 general elections, 6(2).

Okodua, H., \& Ewetan, O. (2013). Stock market performance and sustainable economic growth in Nigeria: A bounds of testing co-integration approach. Canadian centre of science and education, journal of sustainable development. https://doi.org/10.5539/jsd.v6n8p84

Okonkwo, N., Ogwuru, H., \& Ajudua, E. (2014). Stock market performance and economic growth in Nigeria: an empirical analysis. European journal of business and management, 6(26).

Olayiwola, V. O. (2014). Turbulent election history: An appraisal precipitating factors in Nigeria. International journal of politics and good governance, 5 .

Osuala, A. E., \& Agbeze, C. (2016). Impact of Election Results on the Performance of the Nigerian Stock Market: A Case of 2015 General Election, ESUT Journal of Accounting, Enugu.

Pantzalis, C., Stangeland, D., \& Turtle, H. (2000). Political elections and the resolution of uncertainty: the international evidence. Journal of banking and finance, 24(10), 1575-1604. https://doi.org/10.1016/S0378-4266(99)00093-X

Poundstone, W. (2008). Gaming the vote: why elections aren't fair and what we can do about it. New York hill and Young.

Ray, M. V., \& Marshall, D. N. (2009). The U.S presidency and the stock market: a political relationship study and of market relationship. Journal research in business and economics

Siokios, F., \& Kapopoulos, P. (2007). Parties, elections and stock market volatility: evidence from smalla open economy. Journal of economics and politics, 19(1), 123-34. https://doi.org/10.1111/j.1468-0343.2007.00305.x

Snowberg, E., Wolfers, J., \& Zitzewitz E. (2007). Partisan impacts on the economy: evidence from prediction markets and close elections. Quarterly journal of economics, 122(2), 807-29. https://doi.org/10.1162/qjec.122.2.807

Suleman, M. T. (2012). Stock market reaction to good and bad political news. Journal of finance and accounting, 4(1), 299-312. https://doi.org/10.5296/ajfa.v4i1.1705

Wisniewski, T. P., Lightfoot, G., \& Lilley, S. (2012). Speculating on Presidential success: exploring the link between the price-earning ratio and approval rating. Journal of economics and finance, 36(1), 106-122. https://doi.org/10.1007/s12197-009-9116-0

Wolfers, J., \& Zitzewitz, E. (2004). Prediction markets. journal of economic perspective, 18(2), 107-26. https://doi.org/10.1257/0895330041371321

Yang, F., Wilson, C., \& Wu, Z. (2014). Investors perception of the benefits of political connections: evidence from China's A-share premiums. Journal of managerial finance, 10(3), 312-331. https://doi.org/10.1108/IJMF-08-2012-0093

Zach, T. (2003). Political Events and the Stock Market: Evidence from Israel. International Journal of Business, 8(3), 243-266. https://doi.org/10.2139/ssrn.420242

\section{Copyrights}

Copyright for this article is retained by the author(s), with first publication rights granted to the journal.

This is an open-access article distributed under the terms and conditions of the Creative Commons Attribution license which permits unrestricted use, distribution, and reproduction in any medium, provided the original work is properly cited. 